\title{
EM CASA
}

Tiago da Cunha Fernandes ${ }^{1}$

Em casa pois. Um lugar é não. Desobsedar o pensamento, deixar o olho percorrente e só. O juízo já não mora aqui. Fantasmas, vultos, espectros penumbras sugestões, outros espiões. Passam. Na solidão as coisas têm direito. Tudo em seu lugar, exatamente onde está - e não. A casa não está ali ou lá/aqui. Casa: maior das miragens. Paredes brancas cinéticas, e o olho da gente confuso nelas. Veja: quantos filmes não passam em menos de um segundo? Quando se acredita estar dentro de casa bate um vento e te acorda em Anadyr, extremo oriente da Rússia. Lá, pode-se sonhar em ser cosmonauta, como Valery Tokarev o foi. Ou simplesmente caminhar até a encosta e contemplar o mar de Bering, sentir o vento do Alasca tocando a ponta do nariz. Também dentro de casa às vezes bate cheiro de figo mexido no tacho, ou um cheiro da Índia segundo o que viu Pasolini. Outra vez - não sei se era sonho - descia num conversível por autoestrada na Tchecoslováquia. Deixava para trás um campo de concentração que era o centro histórico de Praga fora de Praga, cercado por arames e pastos. Judeus velhos e vestidos de preto, cada vez mais distantes, acenavam de um outro tempo, impenetrável. Em casa os japoneses não vêm chipar ninguém. Ao contrário, ensinam-nos a presença do vazio, e rir dessa brincadeira. Apesar de os móveis aparentarem estáticos em casa, eles distribuem eras geológicas em cada gesto. Por exemplo: um outro encostou a coluna numa cadeira de ferro e sentiu oxigênio do éon Proterozoico invadindo seus pulmões. Em casa as coisas passam, e umas são ditas outras não. Algumas palavras e conjugações enterramos, e esquecê-las foi obra do tempo. Falar em vida ou morte não saberíamos o que quer dizer. Não faz diferença. Em realidade então, do tipo “a única real”, apenas espreitamos com distanciamento os jornais que passam em casa e não assinamos nem folheamos. Inclusive, muitas vezes as notícias nos servem como entorpecente, eventualmente pra quebrar a rotina das pedras, pois ninguém é de ferro. Outro dia entrou (?) em casa uma casta pretensiosa por reduzir tudo ao hoje, dia tal do mês então. Uma espécie de ansiose por consistência. Ao cair em si percebeu: em casa não tinha saída nem relógio ou calendário, e num segundo de pânico granulou-se em mil. Atenção: aqui em casa uma categoria de vento catabático inviabiliza fixações, e não há gelo que ele não derreta a cem nós.

\footnotetext{
${ }^{1}$ Mestrando em Estudos Comparados em Literaturas de Língua Portuguesa pelo Departamento de Letras Clássicas e Vernáculas da Faculdade de Filosofia, Letras e Ciências Humanas da Universidade de São Paulo. Prof. orientador: Mauricio Salles Vas concelos.
} 